Chapter 8

\title{
Nutritional, Therapeutic, and Prophylactic Properties of Vigna subterranea and Moringa oleifera
}

\author{
Victoria Adaora Jideani and \\ Claudine Florett Diedericks \\ Additional information is available at the end of the chapter \\ http://dx.doi.org/10.5772/57338
}

\section{Introduction}

\subsection{Bambara groundnut}

Bambara groundnut (Vigna subterranea (L.) Verdc.) [BGN] is an easy-to-cultivate legume seed classified under the family Fabaceae, sub-family Faboidea and genus Vigna [1]. Two botanical varieties exist, namely $V$. subterranea var. spontanea (wild varieties) and $V$. subterranea var. subterranea (cultivated varieties). BGN originated in West Africa from the Bambara district near Timbuktu and is now widely grown throughout tropical Africa, Indonesia, Malaysia, Sri Lanka, Central and South America and some parts of Northern Australia [2-4]. BGN is known by many common names such as Madagascar groundnut, baffin pea, voandzou, indhlubu, underground bean, nzama [Malawi], Epa-Roro [Nigeria], jugo beans [South Africa] and Nyimo beans [Zimbabwe] $[1,5]$. Considered as one of the main attributes of BGN, is its tolerance of poor soils and drought, as well as its ability to yield in conditions in which groundnut fails completely. BGN also has an extremely tough seed coat, which makes it resistant to weevil attack and allows for storage of the seeds for long periods without loss [6]. Favourable characteristics making BGN an ideal crop includes its ability to be intercropped with other crops (i.e. maize, babala and sorghum), therefore not taking up areas designated to crops seen as more lucrative/important, its abundance in nitrogen which improves soil fertility and makes it useful in crop rotation, and the possibility to be grown without the use of expensive chemicals and fertilisers which are usually difficult to obtain in isolated areas [4].

BGN is propagated by its seeds which can be bought at local markets or are retained from the previous harvest. The larger seeds are used for cultivation and to retain maximum viability the seeds are dehulled before sowing [5]. As a leguminous annual short-day plant, BGN is 
grown for its underground seeds. Similar to the peanut, the BGN plant grows close to the ground and pods and seeds are formed on or below the soil surface [5]. Depending on the cultivar and weather conditions, the BGN plant matures in three to six months. The flowers and pods have been identified as essential parts of the plant [7]. The onset of flowering is $30-$ 35 days after sowing, followed by pod development 30 days after the fertilisation process and the seeds developing after the pods in ten days. Pods are approximately $1.5 \mathrm{~cm}$ long, they may be wrinkled and slightly oval or round shaped containing one to two seeds. Pod colour varies from yellowish-white for unripe pods to yellowish-brown or purple for mature pods [2, 6]. BGN seeds are usually round, hard and smooth and vary in size. The colour of the seeds vary from black, dark-brown, red, white, cream or a combination of these colours and it may also be speckled with or without hilum colouration $[1,6]$. Illustrations of the BGN plant and various seed varieties are shown in Figure 1.

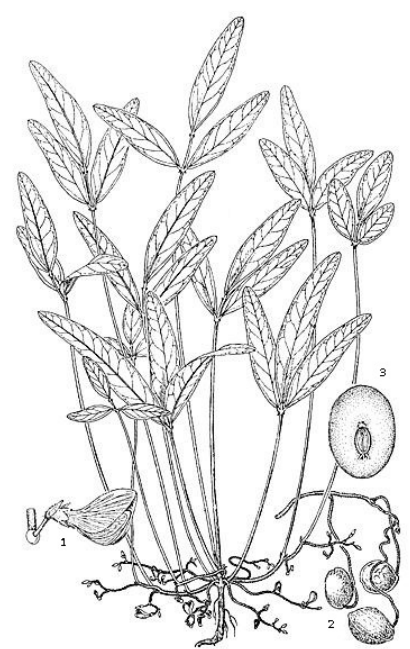

A

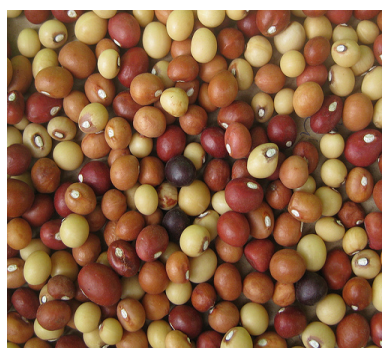

B

Figure 1. Bambara groundnut plant and seeds (A) Bambara groundnut flowering plant (1 - flower, 2 - fruits, 3 seed); (B) Several varieties of Bambara groundnut seeds [8-9]

\subsection{Moringa oleifera}

The family of plants Moringaceae consists of 13 species outlined in Table 1 . Out of the 13 species only M. oleifera has been accorded extensive research and development. They are important multipurpose crops in Africa and India. The species reported to have originated in India and Africa, are now grown around the world. Major production include Ghana, Senegal and Malawi, smaller production are in New Zealand and Fiji and more recent production in Nicaragua and Bolivia [10]. Moringa species are highly tolerant to arid conditions due to the formation of very large tuberous roots, and hence are often important famine foods [11]. Some common names for M. oleifera are detailed in Table 2. Moringa is a medium sized tree of $10 \mathrm{~m}$ 
height, with a straight trunk (10-30 cm thick), whitish or gray, corky bark with longitudinal cracks. It has a tuberous taproot whose presence helps the species' tolerance to drought conditions. The tree is normally umbrella shaped with a lax crown of graceful, airy foliage, whose feathery effect is due to the finely tripinnnate division of the leaves (Figure 2). The leaves are densely crowded at the tops of the branchlets [12].

\begin{tabular}{ll}
\hline Species & Origin \\
\hline Moringa oleifera & India \\
\hline M. drouhardii & Madagascar \\
\hline M. cocanensis & India \\
\hline M. arborea & North Eastern Kenya \\
\hline M. hildebrandtii & Madagascar \\
\hline M. oleifera & India \\
\hline M. borziana & Kenya and Somalia \\
\hline M. ovalifolia & Namibia and extreme southwestern Angola \\
\hline M. peregrina & Horn of Africa, Red sea, Arabia \\
\hline M. longituba & Kenya, Ethiopia, Somalia \\
\hline M. stenopetala & Kenya, Ethiopia \\
\hline M. pygmaea & Northern Somalia \\
\hline M. rivae & Kenya, Ethiopia \\
\hline M. ruspoliana & Kenya \\
\hline Adapted from [12] & \\
\hline
\end{tabular}

Table 1. Moringa species ${ }^{1}$

\section{Food uses of the crops}

\subsection{Bambara groundnut}

Primarily grown for human consumption, BGN seeds are consumed in various ways in both immature and fully matured form. Whilst immature, the BGN seeds may be consumed fresh (raw), grilled or it may be boiled before consumption. These seeds are also more palatable compared to the mature seeds which are hard. To soften the mature seeds and render them more pleasant tasting and sweet, the seeds are boiled or roasted [7, 5]. Immature seeds are frequently consumed as a snack by boiling the fresh seed with salt or roasting the seeds, and may also be pounded with or without hulls and boiled into a stiff porridge [8, 4, 13]. Mature seeds may be consumed as is by boiling in water, or it is often ground into flour and consumed as porridge by mixing the flour with butter or oil. The seeds may also be dried, boiled and 
consumed with plantains or maize [7-8]. Traditional uses of BGN inherent to certain areas in Africa are summarised in Table 3. Despite the many uses of BGN, the crop still remains underutilised due to several negative connotations such as being traditionally grown by women, an indigenous crop consumed by the poor in rural areas (from there the name "a poor man's food"), not being considered a lucrative cash crop and the difficulty in cooking and costs (including time, water and fuel) associated with cooking the seeds [4].

\begin{tabular}{ll}
\hline Language & Common name \\
\hline English & Moringa, horseradish tree, drumstick tree, sujuna, ben tree, ben oil tree \\
\hline French & Ben ailé, ben oléifère, benzolive, arbre radis du cheval \\
\hline Spanish & Ben, árbol del ben, paraiso, morango, Moringa \\
\hline Portuguese & acácia branca, marungo, muringa, moringuiero; cedro (Brazil) \\
\hline Arabic & ruwag, alim, halim, shagara al ruwag (Sudan) \\
\hline Swahili & mzunze, mlonge, mjungu moto, mboga chungu, shingo \\
\hline German & Behenbaum, Behenussbaum, flügelsaniger Bennussbaum, Pferderettichbaum \\
\hline Italian & Sàndalo ceruleo Fon: kpatima, yovokpatin,kpano,yovotin \\
\hline Gun & èkwè kpatin, kpajima
\end{tabular}

Nigeria

\begin{tabular}{ll}
\hline Yoruba \& Nago & $\begin{array}{l}\text { èwè igbale, èwè ile, èwè oyibo, agun oyibo, ayun } \\
\text { manyieninu, ayèrè oyibo }\end{array}$ \\
\hline Fulani & gawara, konamarade, rini maka, habiwal hausa \\
\hline Hausa & $\begin{array}{l}\text { zogall, zogalla-gandi, bagaruwar maka, bagaruwar masar, shipka hali, shuka halinka, } \\
\text { barambo, koraukin zaila, rimin turawa }\end{array}$ \\
\hline Ibo & Ikwe oyibo \\
\hline Senegal & nebeday \\
\hline Philippines & malunggay or malungai (Tagalog) \\
\hline India & sujuna, sajina, lopa, horseradish or drumstick tree \\
\hline Haiti & benzolive (Haitian Creole) \\
\hline
\end{tabular}

'Source: [12]

Table 2. Moringa common names ${ }^{1}$

Several research investigations are therefore aimed at highlighting the potential value of BGN as a sustainable food security crop. As in [14], milk was prepared from BGN by soaking the seeds in water, followed by homogenisation of the liquid and removal of the insoluble material. Acceptable BGN milk was obtained, and sensory analysis revealed panellists' preference for BGN milk in colour and taste compared to milk produced from soybean, cowpea and pigeon- 
pea. More recently, the functional properties of BGN flour and protein and starch fractions have also been investigated, as a means of better utilisation of this underutilised crop in food applications [15-19, 3].

\subsection{Moringa oleifera}

Moringa tree yields at least four different edibles namely pods, leaves, seeds and roots [12]. Figure 3 outlines some of the food uses of Moringa. The immature pods are the most valued and widely used of all the tree parts as it contains all the essential amino acids along with many vitamins and other nutrients. The tender pods have the general characteristics of a succulent string bean. It can be eaten raw or prepared like green peas or green beans. In India, they are usually added to curries and sometimes sliced, blanched and canned. The mature pods quickly turns tough as thick as a pencil and are too fibrous to eat like the string beans. In that form they are called drumsticks. However, they are cut into pieces to release the sweet frothy inside material which are well known ingredients in pickles in India.

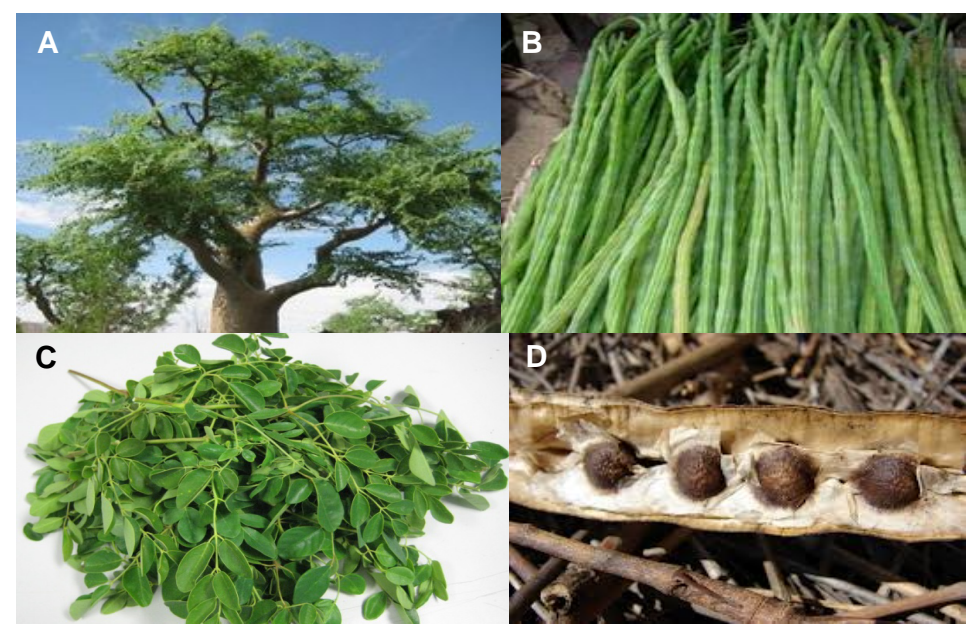

Figure 2. Part of Moringa tree (A) Moringa tree; (B) Moringa pods; (C) Moringa leaves and (D) Moringa pods with the seeds (www.iloveMoringa.com)

The fresh leaves are eaten as greens, in salads, in vegetable curries, as pickles and for seasoning. The dried leaves are crushed or pound and sifted into leaf powder which can then be added to sauces and foods as condiment. The flowers must be cooked and are eaten either mixed with other foods or fried in batter, and have been shown to be rich in potassium and calcium.

The seeds are often referred to as peas and can be used from the time they appear until they turn yellow and their shells begin to harden. They can be cooked like green peas. Hardened mature seeds are bitter and can be pressed yielding $38-40 \%$ of non-drying, edible oil which is clear, sweet and odourless and never becomes rancid and burns without smoke; its nutri- 
tional value resembles olive oil [20]. The seed powder can be used for water treatment where the powder coagulates solids and removes $90-99 \%$ bacteria.

The thickened root is used as substitute for horseradish although this is now discouraged as it contains alkaloids, especially moriginine, and a bacteriocide, spirochin, both of which can prove fatal following ingestion. Older roots and root bark are good sources of tanning agents.

\begin{tabular}{|c|c|c|}
\hline Country & BGN food uses & Source \\
\hline Cameroon & $\begin{array}{l}\text { Testa-free fresh seeds - consumed as a complete meal by cooking } \\
\text { with seasoning, or ground to prepare a traditional pudding } \\
\text { sometimes with addition of taro leaves }\end{array}$ & [21] \\
\hline Northern Ghana & $\begin{array}{l}\text { Dry BGN seeds - boiled and crushed seeds used to form cakes/ } \\
\text { balls followed by frying and adding to stews; BGN is also made } \\
\text { into a paste and used in traditional dishes 'tubani' (steamed bean } \\
\text { paste) and 'koose'/'akla' (fried bean paste) }\end{array}$ & [22-23] \\
\hline Southern Ghana & $\begin{array}{l}\text { 'Aboboi' - prepared by soaking BGN seeds overnight followed by } \\
\text { boiling (with/without capsicum pepper and salt) to produce a } \\
\text { type of porridge/blancmange; served with 'gari' or plantain (ripe, } \\
\text { fried or mashed) }\end{array}$ & \\
\hline $\begin{array}{l}\text { Kenya - Kambe \& Giriama } \\
\text { tribes }\end{array}$ & $\begin{array}{l}\text { Dry BGN seeds are prepared by removal of the seed coat through } \\
\text { pounding, winnowing and boiling the seeds until cooked; cooked } \\
\text { seeds are pounded and mixed with coconut juice - this } \\
\text { preparation is cooked and stirred until smooth, and served with } \\
\text { 'ugali' or rice }\end{array}$ & {$[24]$} \\
\hline Nigeria & $\begin{array}{l}\text { Paste prepared from BGN flour used in preparation of 'moi moi' } \\
\text { and 'akara' (bean balls); 'okpa' (steamed gel prepared by slurry of } \\
\text { BGN) }\end{array}$ & {$[25-26]$} \\
\hline South Africa & $\begin{array}{l}\text { BGN (sometimes with peanuts) are added to millet or maize and } \\
\text { the mixture boiled to form a stiff dough; this dough is salted and } \\
\text { made into a ball known as 'tshidzimba' (Venda), 'sekome' } \\
\text { (Sesotho) or 'tihove' (Shangaan) }\end{array}$ & [27] \\
\hline
\end{tabular}

Table 3. Some food uses of Bambara groundnut in parts of Africa

\section{Nutritional characteristics}

\subsection{Bambara groundnut}

BGN seeds contain on average $63 \%$ carbohydrate, $19 \%$ protein and $6.5 \%$ fat; amounts which are regarded as sufficient to make the seed a complete food [1]. Reference [4] compared the nutritional composition of BGN with more commonly utilised and commercialised grain 
legumes, and BGN compared favourably (see Table 4). The high carbohydrate content of BGN is mainly composed of starch and non-starch polysaccharides [1], fractions which are important in the human diet providing energy and imparting several physiological functions. BGN is also rich in calcium, potassium, iron and nitrogen [4, 6]. In [28] the proximate composition of seeds, flour and seed coats from different BGN varieties were compared. Results for BGN seeds and flour showed no big differences, concluding that the inherent nutrients would be provided in either raw or processed (milled) form. Nti [22] evaluated the chemical composition of five BGN varieties as well as the effects of different processing conditions on the chemical, mineral and anti-nutritional composition of BGN flour samples. The moisture content of all varieties (ranging from $8.8 \pm 0.22-9.8 \pm 0.23 \%$ ) indicated good storage stability of BGN seeds. An increase in tannins content were observed in darker-coloured varieties, with black whiteeye BGN having the highest tannin content $(14.92 \pm 0.85 \mathrm{mg} \mathrm{CE} / \mathrm{g})$.
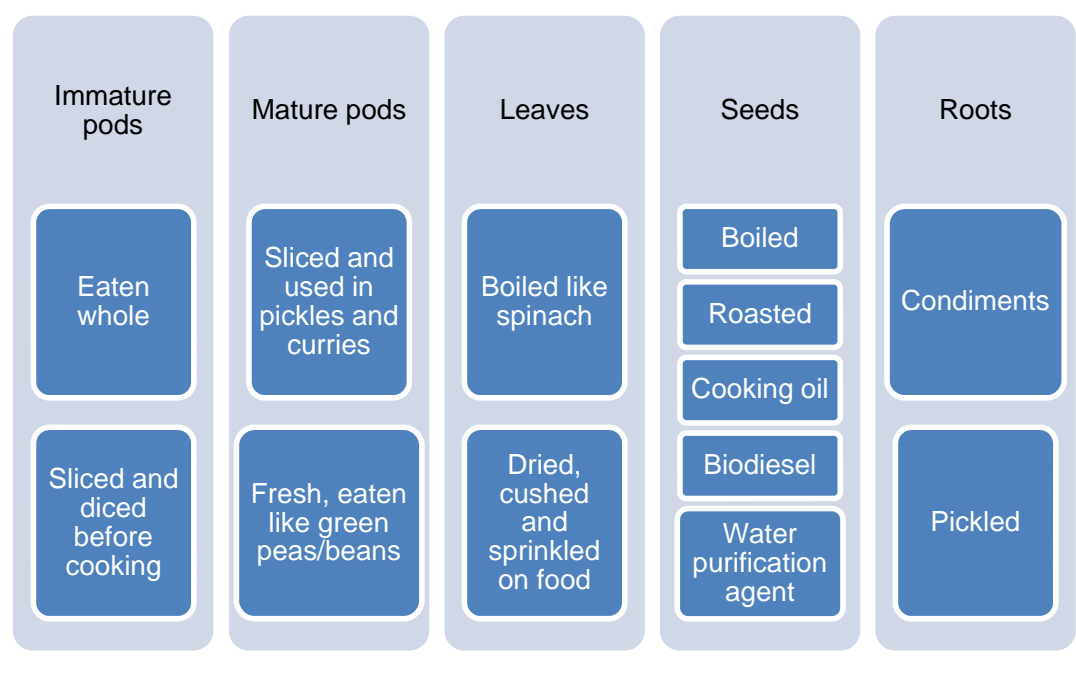

Figure 3. Some food uses of Moringa tree

These anti-nutritional components are mainly found in the seed coat and as in common beans, their concentration are correlated with the colour of the seeds [1]. Dehulling and boiling with dehulling having significant effects on the protein and tannins content of all varieties. Protein content which was highest in the undehulled $(27.35 \pm 0.27 \%)$ black white-eye variety as compared to the other varieties, increased significantly $[\mathrm{p}<0.05]$ when dehulled $(28.55 \pm 0.26 \%)$ and boiled with dehulling $(28.61 \pm 0.51 \%)$. Tannins content in undehulled black white-eye BGN flour $(15.40 \pm 0.39 \mathrm{mg} \mathrm{CE} / \mathrm{g})$ decreased significantly $[\mathrm{p}<0.05]$ when the sample was dehulled $(1.16 \pm 0.12 \mathrm{mg} \mathrm{CE} / \mathrm{g})$ and even more so when boiling and dehulling $(0.09 \pm 0.02 \mathrm{mg} \mathrm{CE} / \mathrm{g})$. These results demonstrate the positive effect of processing conditions on the nutritional properties of BGN, which could lead to increased utilisation in especially weaning products in which high-protein formulations are important. 
The highly nutritious content of BGN and its unusually high content of the sulphurcontaining essential amino acid methionine, makes BGN an important crop to consider for food security [4].

\begin{tabular}{lcccc}
\hline & Bambara groundnut & Soybean & Chickpea & Cowpea \\
\hline Calories (kCal) & 390.0 & 416.0 & 364.0 & 343.0 \\
\hline Protein $(\mathrm{g})$ & 20.8 & 36.5 & 19.3 & 23.8 \\
\hline Carbohydrates $(\mathrm{g})$ & 61.9 & 30.2 & 60.6 & 59.6 \\
\hline Fat $(\mathrm{g})$ & 6.6 & 19.9 & 6.0 & 2.1 \\
\hline
\end{tabular}

${ }^{1}$ Adapted from [4]

Table 4. Nutritional composition of BGN and some commonly utilised legumes ${ }^{1}$

\subsection{Moringa oleifera}

M. oleifera leaves are good source of protein, $\beta$-carotene, vitamins, A, B, C and E, riboflavin, nicotinic acid, folic acid, pyridoxine, amino acids, minerals and various phenolic compounds [29-30]. Moringa oleifera leaf powder (25 g daily) is said to give a child the recommended daily allowance for protein $(42 \%)$, calcium (125\%), magnesium (61\%), potassium (41\%), iron (71\%), vitamin A (272\%), and vitamin C (22\%). Gram for gram, M. oleifera leaves contain seven times the vitamin $C$ in oranges, four times the calcium in milk, four times the $\beta$-carotene in carrots, twice the protein in milk and three times the potassium in bananas [31-33].

Leaves of M. oleifera are rich in palmitic (16:0) and linolenic (18:3) acids whereas the seeds are predominated by oleic acid (18:1). The roots are rich in palmitic and oleic acid whereas the stems and twigs are rich in palmitic acid [34]. It is becoming popular not only among the lower socio-economic class, but in the entire society irrespective of one's socio-economic background and health status.

\section{Phytochemical properties of the crops}

\subsection{Bambara groundnut}

Some phytochemistry studies have been done on species from the genus Vigna, with most focussing on $V$. unguiculata (cowpea) and limited information available on $V$. subterreanea. Pale et al. [35] investigated the anthocyanins present in bambara groundnut through column and preparative thin-layer chromatography. Three anthocyanins (delphinidin 3-O- $\beta$-glucoside, petunidin 3-O- $\beta$-glucoside and malvidin 3-O- $\beta$-glucoside) were identified. Anthocyanins have many beneficial effects on health, and further investigation into the health properties associated with BGN consumption is needed. In a study by [36], eleven species of Vigna were surveyed for canavanine, proanthocyanidin and flavonoid profiles. Canavanine, delphinidin 
and cyanidin were absent in BGN seeds. The absence of canavanine is consistent in the species of Vigna. The flavonoid profiles revealed that the four BGN varieties studied accumulated four types of kaempferol glycosides. In all Vigna species, the prevalent flavonoid appears to be kaempferol. Kaempferol-3-O-glucoside-7-rhamnoside seemed to be restricted to BGN. As a polyphenol antioxidant, kaempferol imparts many health benefits and reduces the risk of many chronic illnesses such as cancer [37]. A recently published article by [38] also reveals the possible components in BGN which could have beneficial effects on health in their study on the effects of gas flaring on the African breadfruit and BGN. Valuable information on the phytochemical properties of BGN was found with high concentrations in the unpolluted samples for oxalate $(0.38 \pm 0.04 \%)$, saponin $(0.24 \pm 0.02 \%)$; vitamin $\mathrm{E}(3.18 \pm 0.15 \mathrm{mg} / 100 \mathrm{~g})$, vitamin C (1.17 $\pm 0.20 \mathrm{mg} / 100 \mathrm{~g})$, vitamin A $(26.05 \pm 0.14 \mathrm{mg} / 100 \mathrm{~g})$ and niacin $(2.10 \pm 0.06 \mathrm{mg} /$ $100 \mathrm{~g})$. The concentrations of oxalate, saponin, alkaloid and flavonoid were increased by gas flaring, whilst the concentrations of vitamins were significantly [ $<0.05]$ reduced. Vitamin A which is important for maintaining good eye-sight and preventing eye diseases [39], were significantly higher $[\mathrm{p}<0.05]$ in the BGN seeds as compared to the other vitamins detected. The information available on phytochemical components of BGN seeds is promising, and should be further investigated to determine and highlight their specific effects on human health, which could greatly influence the current underutilised status of this crop.

\subsection{Moringa oleifera}

Strickly speaking, phytochemicals are non-nutritive chemicals produced by plants which may have an impact on health, or on flavour, texture, smell or colour of the plants. Plants produce these chemicals to protect themselves but recent research demonstrates that they can also protect humans against diseases. The phytochemicals include the alkaloids, anthocyanins, carotenoids, coumestans, flavan-3-ols, flavonoids, hydroxycinnamic acids, isoflavones, lignans, monophenols, monoterpenes, organosulfides, phenolic acids, phytosterols and saponins. Each phytochemicals work differently. M. oleifera contains various phytochemicals namely, carotenoids, vitamins, minerals, amino acids, sterols, glycosides, alkaloids, flavonoids and phenolics [40, 29]. Table 5 details the phytochemicals found in M. oleifera. Moringa species are rich sources of various phytochemicals including uncommon sugar-modified glucosinolates, although there are only details on quantity and profiles for M. oleifera, $M$. peregrine and M. stenopetala [34, 41-42]. The predominant glucosinolate is 4-O-( $\alpha$-L-rhamnopyranosyloxy)benzylglucosinolate (glucomoringin) and depending on the tissues three mono-acetylrhamnose isomers of this glucosinolate have also been detected [41, 43]. Chlorogenic acids and flavonols have been reported in different tissues of M. oleifera and M. stenopetala but there is no information for other Moringa species [34, 40-41, 44-45]. The flavonoid profile was found to be quite complex and was predominated by flavonol glycosides (glucosides, rutinosides and malonylglucosides of quercetin, kaempferol and isorhamnetin). The predominant core aglycones are flavonols: quercetin > kaempferol > isorhamnetin. The leaves had the highest and most complex flavonoid contents, and no flavanoids were detected in roots or seeds. The antioxidant activity of leaves from $M$. oleifera was shown to be very high due to the high concentrations of polyphenolics [46-47]. Therefore $M$. oleifera tissues could be an important dietary source of antioxidant polyphenolics. 
Guevara et al. [48] isolated eight compounds from the seeds of M. oleifera namely, O-ethyl-4( $\alpha$-L-rhamnosyloxy)-benzyl carbamate, 4-( $\alpha$-L-rhamnosyloxy-benzyle isothiocyanate, niazimicin, niazirin, $\quad \beta$-stiosterol, $\quad$ glycerol-1-(9-octadecanoate), $3-\mathrm{O}-\left(6^{\prime}\right.$-O-oleoyl- $\beta$-dglucopyranosyl)- $\beta$ sitosterol and $\beta$-sitosterol-3-O- $\beta$-d-glucopyranoside. 4 - $(\alpha$-L-rhamnosyloxybenzyle isothiocyanate, niazimicin and $\beta$-sitosterol-3-O- $\beta$-d-glucopyranoside showed significant inhibitory activity against Epstein-Barr virus-early antigen (EBV-EA) and niazimicin in particular was found to have potent antitumor promoting acitivity in vivo in the twostage carcinogenesis in mouse skin. They proposed that niazimicin could be a potent chemopreventive agent in chemical carcinogenesis. Beta-sitosterol acts against some form of cancer and was found to reduce the growth of prostate and colon cancer cells. Other medical benefits of beta-sitosterol are boosting of immune defense, anti-inflammatory, normalising blood sugar, healing of ulcers and alleviating cramps.

Niaziridin and niazirin are present in leave and pods, respectively and are not detected in the bark of M. oleifera. Relatively higher amount of niazirin is present in leaves in comparison to the pods, while niaziridin content was about three times higher in the pods than the leaves [49]. Niaziridin rich fraction of $M$. oleifera pods enhances the bioactivity of commonly used antibiotics such as rifampicin, tetracycline and ampicillin against gram positive and negative bacteria and also facilitates the absorption of drugs, vitamins and nutrients through the gastrointestinal membrane thus increasing their bio-availability [50]. Therefore, niaziridin can be used in combination therapy with drugs and nutrients resulting in reduced drug associated toxicity, reduced cost and duration of chemotherapy [49]. Hence, fruits of M. oleifera contain antitumor and anti-inflammatory compounds of the glycoside type (i.e. niazirin, niazimicin, niazicin A).

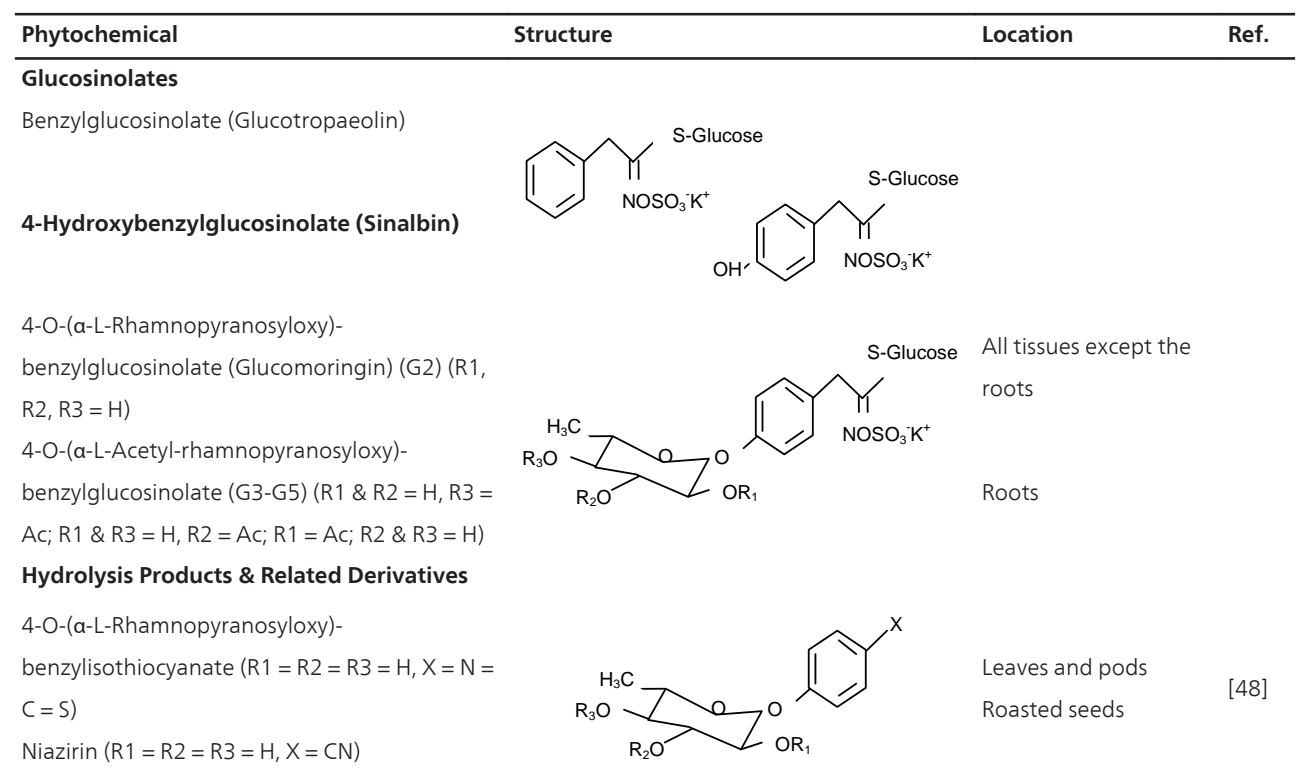




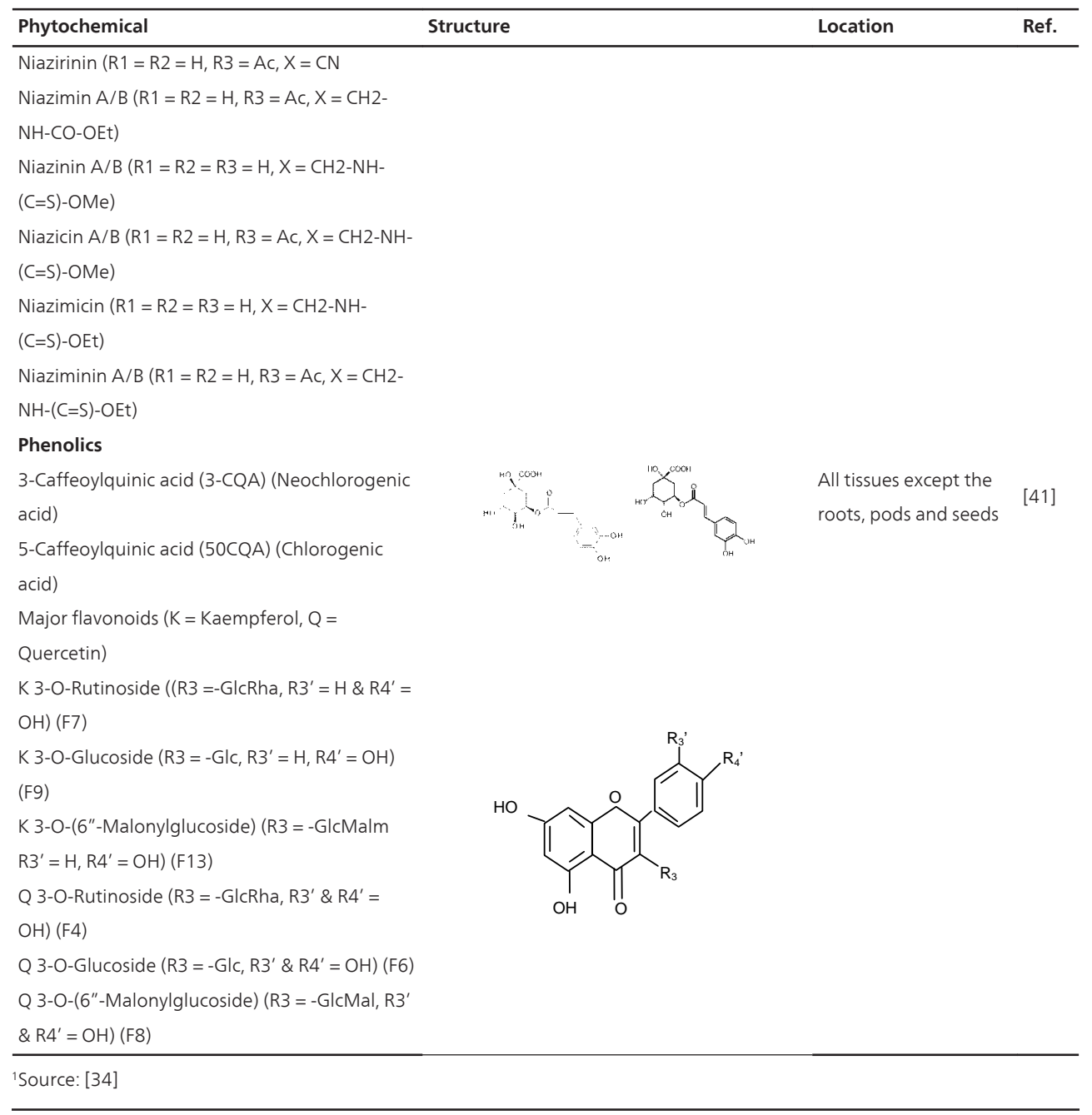

Table 5. Phytochemicals found in M. oleifera?

Polyphenolic compounds exist widely in the plant kingdom and are used in humans to modulate lipid peroxidation involved in atherogenesis, thrombosis and carinogenesis due to their antioxidant activity and anti-inflammatory action [40,51]. Both aqueous and acetone extracts of M. oleifera leaves have potent antioxidant activities; however, Moyo et al. [52] reported higher values of phenols, flavonoids, flavonol and proanthocyanidins in acetone extract of $M$. oleifera leaves than the aqueous extract. Similar observation was reported by other researchers [40,46,53-54]. The ability of the extracts to adsorb and neutralise free radicals or decompose peroxides are attributed to the synergistic effect of phenolic compounds in the M. oleifera. The redox properties, presence of conjugated ring struc- 
tures and carboxylic group which can inhibit lipid peroxidation are responsible for its ability as free radical scavengers [55].

The aqueous extract of leaf (LE), fruit (FE) and seed (SE) of M. oleifera could significantly inhibit the $\mathrm{OH}$-dependent damage of pUC18 plasmid DNA with an activity sequence of LE > FE > SE. Gallic acid, chlorogenic acid, ellagic acid, ferulic acid, kaempferol, quercetin and vanillin were present in the extracts. The leaf extract was comparatively higher in total phenolics [105.04 $\mathrm{mg}$ gallic acid equivalents (GAE/g)], total flavonoids [31.28 mg quercetin equivalents (QE/g)] and ascorbic acid $(106.95 \mathrm{mg} / 100 \mathrm{~g})$ with better antioxidant activity (85.8\%), anti-radical power (74.3), reducing power [1.1 ascorbic acid equivalents (ASE/ml)], inhibition of lipid peroxidation, protein oxidation, $\mathrm{OH}$-induced deoxyribose degradation and scavenging power of superoxide anion and nitric oxide radicals than did the FE, SE and standard $\alpha$-tocopherol [56]. Many gram negative bacteria such as Erwinia carotovora, Enterobacter agglomerans, Chromobacterium violaceum and Pseudomonas aeruginosa use $\mathrm{N}$-acyl homoserine lactones (AHLs) signal molecules to monitor their own population density. At a threshold population density, AHLs interact with cellular receptors and trigger the expression of a set of target genes including virulence, antibiotic production, biofilm formation, bioluminescence, mobility and warming, in a process called "quorum sensing" (QS) [57]. The discovery of the QS system and its critical role in bacteria virulence and survival has revealed a novel way to attack and attenuate bacterial pathogenicity. The major advantage of this novel strategy for anti-infective therapy is that it circumvents the problem of antibiotic resistance, which is intimately connected to the use of conventional antibacterial agents, as it specifically interferes with the expression of pathogenic traits rather than to impede growth of the bacteria. The efficacy and toxicity of previous reported QS blockers (halogenated furanones) have been important concerns. Hence, attention has been focused on identification of such QS blockers from natural and non-toxic sources for the development of novel non-antibiotic drugs for treating bacterial diseases in humans as well as in other animals. Singh et al. [56] reported that the leaf and the fruit extracts of $M$. oleifera inhibited violacein production, a QS-regulated behaviour in Chromobacterium violaceum 12472 . This provides evidence on $M$. oleifera as natural antioxidant for its capacity to protect organism and cell from oxidative DNA associated with aging, cancer and denegerative diseases as well as inhibit lipid peroxidation and bacterial QS. Thus, M. oleifera may serve as an ideal ingredient for functional food, nutraceutical and bio-pharmaceutical industries.

The seeds of Moringa oleifera contain 4 ( $\alpha$-L-Rhamnosyloxy) benzyl isothiocyanate and benzyl isothiocyanate. These are antimicrobial agents effective against several bacteria and fungi. The minimal bactericidal concentration in vitro is $40 \mu \mathrm{mol} / \mathrm{l}$ for Mycobacterium phlei and $56 \mu \mathrm{mol} / \mathrm{l}$ for Bacillus subtilis [58]. Singh et al. [10] identified ten phenolic compounds (gallic acid, pcoumaric acid, ferulic acid, caffeic acid, protocatechuric acid, cinnamic acid, catechin, epicatechin, vanillin and quercetin) from defatted $M$. oleifera seed flour. These natural plant phenolics could be a good source of antioxidants and antimicrobials for food and pharmaceutical industries. 


\section{Therapeutic and prophylactic properties of the crops}

\subsection{Bambara groundnut}

The medicinal role of BGN is mainly based on information obtained from communities in several parts of Africa, where this crop is reportedly responsible and useful for treatment of various ailments. As a treatment for diarrhoea, a mixture of BGN and water from boiled maize are consumed. Raw BGN seeds are chewed and swallowed by pregnant women to alleviate the nausea associated with pregnancy [7]. The medicinal value of the crop have also been highlighted and reviewed by [59]. The following uses of BGN as traditional medicine have been noted by the authors (i) In several countries in sub-Saharan Africa, BGN plays an important role in the diets of especially young rural children as it helps in overcoming the protein deficiency Kwashiorkor; (ii) The Igbos tribe in Nigeria use the seeds for treatment of venereal diseases; (iii) To treat polymenorrhea it is recommended that BGN seeds be roasted before consumption; (iv) The water in which BGN seeds are boiled is used as treatment for internal bruising, and a mixture of water and crushed seeds are prescribed for treatment of cataracts; (v) BGN seeds have the highest concentration of soluble fibre as compared to other beans; this could contribute to the reduction of heart disease incidence and prevention of colon cancer; (vi) Surveys amongst local communities in northern Côte $\mathrm{d}^{\prime}$ Ivoire revealed that the BGN seeds are mainly used for medical treatments as opposed to other parts of the plant. The seeds are used to treat anemia, ulcers (black BGN variety mixed with an unidentified plant) and menorrhagia during pregnancy (hemostatic drink prepared by a mixture of BGN flour and Pupalia lappacea (L.) Amaranthaceae dissolved in water). The traditional uses of BGN to treat several ailments are noteworthy, and present a gap for detailed study on the pharmaceutical value of the crop. This would provide yet another means of highlighting the potential of BGN as an underutilised legume and tap into ways of encouraging more sustained production and use of BGN.

\subsection{Moringa oleifera}

Besides the rich nutritional value of $M$. oleifera it has curative and prophylactic properties [24]. Almost all the parts (root, bark, gum, leaf, pods, flowers, seed and seed oil) of M. oleifera have been used for various ailments including the treatment of inflammation and infectious diseases along with cardiovascular, gastrointestinal, haematological, hepatorenal disorders, diabetes mellitus, CNS depressant, and for antifertility effect [40]. The plant has been used for the treatment of ascites, rheumatism and for the enhancement of cardiac function. The seed extract have been reported to be administered nasally in diseases like rhinitis and the dried seeds used successfully as an 'anti-allergic' agent by the Ayurvedic practitioners [60]. Mahajan [61] reported an antiarthritic activity of ethanolic extract of seeds of $M$. oleifera against chemical induced rheumatoid arthritis as well as an antiasthmatic activity against immune-mediated inflammatory responses in rat [62]. M. oleifera seed extract can act against CCl4-induced liver injury and fibrosis in rats by a mechanism related to its 
antioxidant properties, anti-inflammatory effect and its ability to attenuate the hepatic stellate cells activation [63].

Siddhuraju and others [40] reported that leaf extracts (water, aqueous methanol, aqueous ethanol) were capable of scavenging peroxyl and superoxyl radicals. The major bioactive compounds of phenolics were found to be flavonoid groups such as quercetin and kaempferol. Moringa leaves are therefore potential source of natural antioxidants. The ethanol leaf extract of Moringa oleifera is used for hypertension [64-66]. The leaves are used as hypocholesterolemic and hypoglycemic agents [64, 67-68]. Additionally, the leaves have been reported for its antitumour [69], antioxidant [46, 54, 70], radio-protective [71-72], anti-inflammatory/diuretic properties [73], antihepatotoxic [74], antifertility [75], antiurolithiatic [76] and analgesic activities [77]. Choudhary and others [78] reported that ethanolic root-bark extract of $M$. oleifera possesses valuable antiulcer, antisecretory and cytoprotective activity in rats and thus can be used as source for an antiulcer drug.

An old report from Southeast Asia says a decoction of bark stimulates menses and is used for "morning after" birth control. In parts of West Africa, Moringa leaves or juice are taken for diabetes and high blood pressure [12]. Traditionally, leaves, fruits, roots and seeds of this plant are used for treating abdominal tumors, hysteria, scurvy, paralytic attacks, helminitic, bladder, prostate troubles, sores and skin infections [32].

Moringa oleifera possess genotoxicity at a high dose $3000 \mathrm{mg} / \mathrm{kg}$ b.wt of the powdered aqueous extract. However, intake is safe at levels $\leq 1000 \mathrm{mg} / \mathrm{kg}$ b.wt. [79].

\section{Harnessing the rich nutritional and health properties of Bambara groundnut and M. oleifera for human nutrition}

Bambara groundnut is a leguminous crop with great potential of sustaining the dietary needs of many people in both rural and urban communities. This indigenous African legume have been frowned upon as a 'poor man's food', but as more information emerges on the rich nutritional profile of BGN the importance of this crop to human nutrition is becoming more evident. In our laboratory we have demonstrated that Bambara groundnut could be used to produce a probiotic beverage as well as a rich source of soluble and insoluble fibre that can be used to enhance the nutrition and textural properties of white bread [80-81].

Moringa could be incorporated into programs on malnutrition. With four times the betacarotene of carrot, Moringa has especial potential for programs dealing with avitaminosis, the vitamin A deficiency that causes 70 percent of childhood blindness. Consumption of diet supplemented with $M$. oleifera leaves could protect against diseases induced by oxidative stress. Many Moringa nutritional supplements exist in the market including Moringa dry leaf powder, capsules, nutrition shake and health booster. Perhaps using the multi mix approach of food product development more food products could be developed especially for programs on malnutrition. 


\section{Author details}

Victoria Adaora Jideani* and Claudine Florett Diedericks

*Address all correspondence to: jideaniv@cput.ac.za

Department of Food Technology, Cape Peninsula University of Technology, Bellville, South Africa

\section{References}

[1] Bamishaiye, O.M., Adegbola, J.A. and Bamishaiye, E.I. Bambara groundnut: an under-utilized nut in Africa. Advances in Agricultural Biotechnology 2011; 1 60-72.

[2] Swanevelder, C.J. Bambara-Food for Africa (Vigna subterranea - bambara groundnut). Pp. 1-16. South Africa: National Department of Agriculture; 1998. p1-16.

[3] Eltayeb, A.R.S.M., Ali, A.O., Abou-Arab, A.A. \& Abu-Salem, F.M. Chemical composition and functional properties of flour and protein isolate extracted from bambara groundnut (Vigna subterranea (L.) Verdc.). African Journal of Food Science 2011; 5(2) 82-90.

[4] De Kock, C. Bambara groundnut. http://www.underutilized-species.org/documents/ Publications/bambara_groundnut_paper.pdf (accessed 03 September 2013)

[5] Stephens, J.M. Bambara Groundnut-Voandzeia subterranea (L.) Thouars. Gainesville, Florida: University of Florida; 2012. http://edis.ifas.ufl.edu/mv014 (accessed 11 June 2013).

[6] Mkandawire, C.H. Review of bambara groundnut (Vigna subterranea (L.) Verdc.) production in Sub-Sahara Africa. Agricultural Journal 2007; 2(4) 464-470.

[7] Directorate Plant Production (DPP). Production guidelines for Bambara groundnuts. Pretoria, South Africa: Department of Agriculture, Forestry and Fisheries; 2011. p1-10.

[8] Brink, M., Ramolemana, G.M. and Sibuga, K.P. Vigna subterranea (L.) Verdc. In: Plant Resources of Tropical Africal Ressources végétales de I'Afrique tropicale (edited by M. Brink \& G. Belay). Wageningen, Netherlands: PROTA4U; 2006. http:// www.prota4u.org/search.asp. (accessed 5 September 2013).

[9] Rulkens, T. Bambara groundnut (Vigna subterranea) from Buzi district in Mozambique. http://www.flickr.com/photos. (accessed 5 September 2013). 
[10] Singh, R.S.G, Negi, P.S. and Radha, C. Phenolic composition, antioxidant and antimicrobial activities of free and bound phenolic extracts of Moringa oleifera seed flour. Journal of Functional Foods 2013 (Article in Press).

[11] Sena, L.P., VanderJagt, D.J., Rivera, C., Tin, A.C., Muhamadu, I., Mahamadou, O., Millton, M., Pastuszyn, A. And Glew, R.H. Analysis of nutritional components of eight famine foods of the Republic of Niger. Plant Foods for Human Nutrition 1998; 52 17-30.

[12] National Research Council (2006). Lost crops of Africa: Volume II: Vegetables. http:// www.nap.edu/catalog/11763.html. (accessed 15 October 2013).

[13] Uebersax, M.A. and Occeña, L.G. Legumes in the diet. In: Encyclopedia of Food Sciences and Nutrition, $2^{\text {nd }}$ Edition (edited by B. Caballero, L. Trugo \& P.M. Finglas). New York: Elsevier Science Ltd; 2003. p3520-3528.

[14] Brough, S.H., Azam-Ali, S.N. and Taylor, A.J. The potential of bambara groundnut (Vigna subterranea) in vegetable milk production and basic protein functionality systems. Food Chemistry 1993; 47 277-283.

[15] Adebowale, K.O., Afolabi, T.A. and Lawal, O.S. Isolation, chemical modification and physicochemical characterisation of bambarra groundnut (Voandzeia subterranean) starch and flour. Food Chemistry 2002; 78 305-311.

[16] Adebowale, K.O. and Lawal, O.S. Comparative study of the functional properties of bambarra groundnut (Voandzeia subterranean), jack bean (Canavalia ensiformis) and mucuna bean (Mucuna pruriens) flours. Food Research International 2004; 37 355-365.

[17] Lawal, O.S., Adebowale, K.O. and Adebowale, Y.A. Functional properties of native and chemically modified protein concentrates from bambara groundnut. Food Research International 2007; 40 1003-1011.

[18] Sirivongpaisal, P. Structure and functional properties of starch and flour from bambara groundnut. Songklanakarin Journal of Science and Technology 2008; 30(1) 51-56.

[19] Yusuf, A.A., Ayedun, H. and Sanni, L.O. Chemical composition and functional properties of raw and roasted Nigerian benniseed (Sesamum indicum) and bambara groundnut (Vigna subterranean). Food Chemistry 2008; 111 277-282.

[20] Tsaknis, J., Lalas, S., Gergis, V., Douroglou, V. and Spiliotis. Characterisation of Moringa oleifera variety Mbololo seed oil of Kenya. Journal of Agricultural and Food Chemistry 1999; 47 4495-4499.

[21] Nguy-Ntamag, F.C. Country Reports: Cameroon. Bambara groundnut Vigna subterranea (L.) Verdc. Promoting the conservation and use of underutilized and neglected crops 9. In: Heller J, Begemann F, Mushonga J. (eds.). Proceedings of the workshop on Conservation and Improvement of Bambara Groundnut (Vigna subterranea (L.) Verdc.). November 1995. Harare, Zimbabwe; 1997. 
[22] Nti, C.A. Effects of bambara groundnut (Vigna subterranea) variety and processing on the quality and consumer appeal for its products. International Journal of Food Science and Technology 2009; 44 2234-2242.

[23] Doku, E.V. Country Reports: Ghana. Bambara groundnut Vigna subterranea (L.) Verdc. Promoting the conservation and use of underutilized and neglected crops 9. In: Heller J, Begemann F, Mushonga, J. (eds.). Proceedings of the workshop on Conservation and Improvement of Bambara Groundnut (Vigna subterranea (L.) Verdc.). November 1995. Harare, Zimbabwe; 1997.

[24] Ngugi, G.W. Country Reports: Kenya. Bambara groundnut Vigna subterranea (L.) Verdc. Promoting the conservation and use of underutilized and neglected crops 9. In: Heller J, Begemann F, Mushonga J. (eds.). Proceedings of the workshop on Conservation and Improvement of Bambara Groundnut (Vigna subterranea (L.) Verdc.). November 1995. Harare, Zimbabwe; 1997.

[25] Obizoba, I.C. Nutritive value of cowpea-bambara groundnut rice mixtures in adult rats. Nutrition Reports International 1983; 27 709-712.

[26] Uvere, P.O., Uwaegbute, A.C. and Adedji, E.M. Effects of malting on the milling performance and acceptability of bambara groundnut (Voandzeia subterranea Thouars) seeds and products. Plant Foods for Human Nutrition 1999; 54 49-57.

[27] Swanevelder, C.J. Country Reports: South Africa. Bambara groundnut Vigna subterranea (L.) Verdc. Promoting the conservation and use of underutilized and neglected crops 9. In: Heller J, Begemann F, Mushonga J. (eds.). Proceedings of the workshop on Conservation and Improvement of Bambara Groundnut (Vigna subterranea (L.) Verdc.) November 1995. Harare, Zimbabwe; 1997.

[28] Ojimelukwe, P.C. and Ayernor, G.S. Oligosaccharide composite and functional properties of flour and starch isolates from four cultivars of Bambara groundnut seeds. Journal of Food Science and Technology 1992; 29 319-321.

[29] Anwar, F., Latif, S., Ashraf, M. and Gilani, A.H. Moringa oleifera: A food plant with multiple medicinal uses. Phytotherapy Research 2007; 21 17-25.

[30] Khalafalla, M.M., Abdellatef, E., Dafalla, H.M., Nassrallah, A.A., Aboul-Enein, K.M. and Lightfoot, D.A. Active principle from Moringa oleifera Lam. leaves effective against two leukemias and a hepatocarcinoma. African Journal of Biotechnology 2010; 9 8467-8471.

[31] Ramachandran, C., Peter, K.V. and Gopalakrishnan, P.K. Drumstick (Moringa oleifera): a multipurpose Indian vegetable. Economic Botany 1980; 34, 276-283.

[32] Fuglie, L.J. Isolation and structure elucidation of new nitrile and mustard oil glycosides from Moringa oleifera and their effect on blood pressure. Journal of Natural Products (1999a); 57 1256-1261. 
[33] Fuglie, L.J. The Miracle Tree. Moringa oleifera: Natural Nutrition for the Tropics. Dakar: Church World Service; (1999b). p. 68.

[34] Amaglo, N.K.; Bennett, R.N.; Lo Curto, R.B., Rosa, E.A.S., Turco, V.L, Giuffrida, A.; Curto, A.L., Crea, F. and Timpo, G.M. Profiling selected phytochemicals and nutrients in different tissue of the multipurpose tree Moringa oleifera L., grown in Ghana. Food Chemistry 2010; 122 1047-1054.

[35] Pale, E., Nacro, M., Vanhaelen, M. and Vanhaelen-Fastré. Anthocyanins from Bambara Groundnut (Vigna subterranea). Journal of Agricultural and Food Chemistry 1997; 45 3359-3361.

[36] Onyilagha, J.C., Islam, S. and Ntamatungiro, S. Comparative phytochemistry of eleven species of Vigna (Fabaceae). Biochemical Systematics and Ecology 2009; 37 16-19.

[37] Chen, A.Y. \& Chen, Y.C. A review of the dietary flavonoid, kaempferol on human health and cancer chemoprevention. Food Chemistry 2013; 138(4) 2099-2107.

[38] Ujowundu, C.O., Nwagou, L.A., Ujowundu, F.N. \& Belonwu, D.C. Effect of gas flaring on the phytochemical and nutritional composition of Treculia Africana and Vigna subterranean. British Biotechnology Journal 2013; 3(3) 293-304.

[39] Nwaogu, L.A. and Ujowundu, C.O. Effect of petroleum hydrocarbon pollution on the nutritional value of ripe guava (Psidium guajava) fruits grown in Imo State, Nigeria. International Journal of Biological and Chemical Sciences 2010; 4(2) 450-455.

[40] Siddhuraju, P. and Becker, K. Antioxidant properties of various solvent extracts of total phenolic constituents from three different agroclimatic origins of drumstick tree (Moringa oleifera Lam.) leaves. Journal of Agricultural and Food Chemistry 2003; 51(8) 2144-2155.

[41] Bennett, R.N., Mellon, F.A., Foidl, N., Pratt, J.H., DuPont, M.S., Perkins, L. and Kroon, P.A. Profiling glucosinolates and phenolics in vegetative and reproductive tissues of the multi-purpose trees Moringa oleifera L. (Horseradish tree) and Moringa stenopetala L. Journal of Agricultural and Food Chemistry 2003; 51 3546-3553.

[42] Fahey, J.W., Zalcmann, A.T. and Talalay, P. The chemical diversity and distribution of glucosinolates and isothiocyanates among plants. Phytochemistry 2001; 56 5-51.

[43] Kjaer, A., Malver, O., El-Menshawi, B. and Reischt, J. Isothiocyanates in myrosinasetreated seed extracts of Moringa peregrina. Phytochemistry 1979; 18 1485-1487.

[44] Lako, J., Trenerry, V.C., Wahlqvist, M., Wattanapenpaiboon, N., Sotheeswaran, S. and Premier, R. Phytochemical flavonols, carotenoids and antioxidant properties of a wide selection of Fijian fruit, vegetables and other readily available foods. Food Chemistry 2007; 101 1727-1741.

[45] Manguro, L.O.A. and Lemmen, P. Phenolics of Moringa oleifera leaves. Natural Products Research 2007, 21. 
[46] Sreelatha, S. and Padma, P.R. Antioxidant activity and total phenolic content of Moringa oleifera leaves in two stages of maturity. Plant Foods for Human Nutrition 2009; 64 303-311.

[47] Verma, A.R., Vijayakumar, M., Mathela, C.S., \& Rao, C.V. In vitro and in vivo antioxidant properties of different fractions of Moringa oleifera leaves. Food and Chemical Toxicology 2009; 47 2196-2201.

[48] Guevara, A.P., Vargas, C., Sakurai, H. Fujiwara, Y., Hashimoto, K. Maoka, T., Kozuka, M., Ito, Y., Tokuda, H. and Nishino, H. An antitumor promoter from Moringa oleifera Lam. Mutation Research 1999; 440 181-188.

[49] Shanker, K, Gupta, M.M., Srivastava, S.K.; Bawankule, D.U.; Pal, A. and Khanuja, S.P.S. Determination of bioactive nitrile glycoside(s) in drumstick (Moringa oleifera) by reverse phase HPLC. Food Chemistry 2007; 105 376-382.

[50] Khanuja, S.P.S., Arya, J.S., Tiruppadiripuliyur, R.S.K., Saikia, D., Kaur, H., Singh, M., Gupta, S. C., Shasany, A.K., Darokar, M.P., Srivastava, S.K., Gupta, M.M., Verma, S.C. and Pal, A. Nitrile glycoside useful as a bioenhancer of drugs and nutrients, process of its isolation from Moringa oleifera. (United States Patent 2005; 6,858,588 B2).

[51] Frankel, E.N., \& Meyer, A.S. The problems of using one-dimensional methods to evaluate multifunctional food and biological antioxidants. Journal of the Science of Food and Agriculture 2000; 80 1925-1941.

[52] Moyo, B., Oyedemi, S., Masika, P.J. and Muchenje, V. Polyphenolic content and antioxidant properties of Moringa oleifera leaf extracts and enzymatic activity of liver from goats supplemented with Moringa oleifera leaves/sunflower seed cake. Meat Science 2012; 91, 441-447.

[53] Frum, Y., \& Viljoen, A.M. In vitro 5-lipoxygenase and antioxidant activities of South African medicinal plants commonly used topically for skin diseases. Skin Pharmacology and Physiology 2006; 19 329-335.

[54] Atawodi, S.E., Atawodi, J.C., Idakwo, G.A., Pfundstein, B., Haubner, R., Wurtele, G., Bartsch, H. and Owen, R.W. Evaluation of the polyphenol content and antioxidant properties of methanol extracts of the leaves, stem, and root barks of Moringa oleifera Lam. Journal of Medicinal Food 2010; 13 710-716.

[55] Oyedemi, S.O., Bradley, G. and Afolayan, A. J. In-vitro and in-vivo antioxidant activities of aqueous extract of Strychnos henningsii Gilg. African Journal of Pharmacy and Pharmacology 2010; 4 70-78.

[56] Singh, B.N., Singh, B.R., Singh, R.L., Prakash, D., Dhakarey, R., Upadhyay, G. and Singh, H.B. Oxidative DNA damage protective activity, antioxidant and anti-quorum sensing potentials of Moringa oleifera. Food and Chemical Toxicology 2009; 47 1109-1116. 
[57] Manefield, M., Rasmussen, T.B., Henzter, M., Steinberg, P., Kjelleberg, S. and Givsko, M. Halogenated furanones inhibit quorum sensing through accelerated LuxR turnover. Microbiology 2002; 148 1119-1127.

[58] Eilert, U., Wolters, B. and Nahrstedt, A. The antibiotic principle of seeds for Moringa oleifera and Moringa stenopetala. Planta Medica 1981; 42(5) 55-61.

[59] Koné. M., Paice, A.G. and Touré, Y. Bambara groundnut [Vigna subterranea (L.) Verdc. (Fabaceae)] usage in human health. In: Nuts and Seeds in Health and Disease Prevention (edited by V.R. Preedy, R.R. Watson \& V.B. Patel). UK: Elsevier Inc.; 2011. p. 192-194.

[60] Chopra, R.N., Chopra, I.C., Handa, K.L., Kapur, I.D. (Eds.), 1938. Chopra's Indigenous Drugs of India. UN Dhur and Sons, Calcutta, India, 1938, p. 110.

[61] Mahajan, S.G., Mali, R.G. and Mehta, A.A. Protective effect of ethanolic extract of seeds of Moringa oleifera Lam. against inflammation associated with development of arthritis in rats. Journal of Immunotoxicology 2007a; 4 39-47.

[62] Mahajan, S.G., Mali, R.G. and Mehta, A.A. Effect of Moringa oleifera Lam. seed extract on Toluene Diisocyanate-induced immune-medicated inflammatory responses in rats. Journal of Immunotoxicology 2007b; 4 85-96.

[63] Hamza, A. A. Ameliorative effects of Moringa oleifera Lam seed extract on liver fibrosis in rats. Food and Chemical Toxicology 2010; 48 345-355.

[64] Siddiqui, S. and Khan, M.I. Pharmacological Study of Moringa pterygosperma. Central Laboratories. Pakistani Council of Science and Industrial Research 1968;p. 268-272.

[65] Kirtikar, K.R. and Basu, K. Indian Medicinal Plants. India: Lalit Mohan Basu MB, Allahabad; 1984. p.677-681.

[66] Nikkon, F., Saud, A., Rahman, M.H. and Haque, M.E. In vitro antimicrobial activity of the compound isolated from chloroform extract of Moringa oleifera Lam. Pakistani Journal of Biological Sciences 2006; 6 1888-1890.

[67] Ghasi, S., Nwobodo, E. and Ofili, J.O. Hypocholesterolemic effects of crude extract of leaf of Moringa oleifera Lam in high-fat diet fed wistar rats. Journal of Ethnopharmacology 2000; 69 21-25.

[68] Dangi, S.Y., Jolly, C.I. and Narayanan, S. Antihypertensive activity of the total alkaloids from the leaves of Moringa oleifera. Pharmaceutical Biology 2002; 40, 144-148.

[69] Aruna, K., Sivaramakrishnan, V.M. Plant products as protective agents against cancer. Indian Journal of Experimental Biology 1990; 28 1008-1011.

[70] Diallo, D., Marston, A., Terreaux, C., Toure, Y., Paulsen, B.S. and Hostettmann, K. Screening of Malian medicinal plants for antifungal, larvicidal, molluscidal, antioxidant and radical scavenging activities. Phytotherapy Research 2001; 15 401-406. 
[71] Rao, V.A., Devi, P.U. and Kamath, R. In vivo radioprotective effect of Moringa oleifera leaves. Indian Journal of Experimental Biology 2001; 39 858-863.

[72] Arora, R., Gupta, D., Chawla, R., Sagar, R., Sharma, A., Kumar, R., Prasad, J., Singh, S., Samanta, N. and Sharma, R.K. Radioprotection by plant products: present status and future prospects. Phytotherapy Research 2005; 19, 1-22.

[73] Cáceres, A., Cabrera, O., Morales, O., Mollinedo, P. and Mendia, P. Pharmacological properties of Moringa oleifera. 1. Preliminary screening for antimicrobial activity. Journal of Ethnopharmacology 1991; 33 213-216.

[74] Ruckmani, K., Kavimani, S., Anandan, R. and Jaykar, B. Effect of Moringa oleifera Lam. on paracetamol-induced hepatoxicity. Indian Journal of Pharmaceutical Sciences 1998; 60 33-35.

[75] Prakash, A.O. Ovarian response to aqueous extract of Moringa oleifera during early pregnancy in rats. Fitoterapia 1988; 59 89-96.

[76] Karadi, R.V., Gadge, N.B., Alagawadi, K.R. and Savadi, R.V. Effect of Moringa oleifera Lam. root-wood on ethylene glycol induced urolithiasis in rats. Journal of Ethnopharmacology 2006; 105 306-311.

[77] Rao, C.V., Ojha, S.K. and Mehrotra, S. Analgesic effect of Moringa oleifera leaf extract on rats. In: Proceedings of the Second World Congress on Biotechnological Developments of Herbal Medicine, Lucknow, India; 2003. p. 42.

[78] Choudhary, M.K.; Bodakhe, S.H. and Gupta, S.K. Assessment of the antiulcer potential of Moringa oleifera root-bark extract in rats. Journal of Acupuncture and Meridian Studies 2013; 6(4) 214-220.

[79] Asare, G.A.; Gyan, B.; Bugyei, K., Adjei, S.A., Mahama, R.; Addo, P., Otu-Nyarko, L., Wiredu, E.K. and Nyarko, A. Toxicity potentials of the nutraceutical Moringa oleifera at supra-supplementation levels. Journal of Ethnopharmacology 2012; 139 265-272.

[80] Jideani, V. A. and Murevanhema, Y.Y. A Bambara groundnut milk beverage and probiotic yoghurt produced therefrom and a method for the production thereof. South Africa- Complete Patent 25 January 2013, 2013/00683.

[81] Jideani, V.A. \& Diedericks, C.F. Dietary fibre from Bambara groundnuts (Vigna subterranea). South Africa Provisional Patent 14 June 2013, 2013/04395. 
